\title{
Developing Javanese Local Curriculum Content Focusing on Literacy to Grow Students' Literacy Culture
}

\author{
Rini Murwati \\ Universitas Negeri Surabaya \\ Surabaya, Indonesia \\ rini117835046@mhs.unesa.ac.id
}

\author{
Bambang Yulianto \\ Universitas Negeri Surabaya \\ Surabaya, Indonesia \\ bambangyulianto@unesa.ac.id
}

\author{
Syamsul Shodiq \\ Universitas Negeri Surabaya \\ Surabaya, Indonesia \\ syamsulsodiq@unesa.ac.id
}

\begin{abstract}
This research is intended to develop Javanese local curriculum document focused on growing students' literacy culture in Javanese subject. Javanese local curriculum focusing on literacy is aimed to meet the demand of teacher in increasing learning quality. The growth of Java literacy culture is the foundation of students' Javanese attitude. This research employed qualitative approach. Then, the research procedures used are from Borg and Gall education research which had been modified. The collecting data method was obtained on developing curriculum and learning process. This research was done through 2014/2015-2015/2016. Furthermore, the instrument and data collecting technique were adjusted with the information needed. Data validation was done by the expert validator and the collaborator. The subjects of this research were students of junior high school at Lamongan region as a little scale experiment and as broad scale experiment. The result of this research was the local content of Javanese curriculum document based on literacy. It was completed with learning tool mode (syllabus, learning plan, worksheet, and manual assessment sheet) and students' literacy culture that grew as an effect of developing curriculum based on literacy. The students experienced language attitude change and were able to produce works anthology, such as narrative "Kembang Mayang" and poetry "Sekar Rinonce".
\end{abstract}

Keywords-local content curriculum; Javanese; literacy; culture literacy; text; language attitude

\section{INTRODUCTION}

Local content subject is a subject at school which load local potential and uniqueness. It meant that the form of local content can be custom which be integrated with any subject at school or an independent subject. The character of local content subject is feature excellent characteristic territory, such as language, art, cultural, and skill. Local content subject at this paper be focused on independent subject. That is Javanese Subject.
Decision of curriculum as local content subject is an authority office territorial, regent/city/province government [1]. Foundation of local content curriculum development is Peraturan Pemerintah (government regulation) number 32 year 2013 about Standar Nasional Pendidikan (National education standard) [2] and Permendikbud (education and cultural ministry regulation) number 81a year 2013 about Implementasi Kurikulum 2013 (implementation of Curriculum 2013) appendix II about Pedoman Pengembangan Muatan Lokal (directive of content local development) [3] refreshed at Permendikbud number 79 year 2014 about Kurikulum Muatan Lokal Kurikulum 2013 (local content curriculum of curriculum 2013) [1]. Based on those regulations, East Java Province made decision that Javanese is an obligate subject for basic and middle education through letter circulated number 045.2/4340/I.03.07/2013 [4]. There is no curriculum 2013 in that letter circulated.

School had not used curriculum 2013 when province made decision that Javanese subject obligated in Jawa Timur province. School had been using the KTSP curriculum 2006 revised 2008. This curriculum focused on knowledge and language skill [5]. This curriculum had not given contribution to incise students' character and ability. Students had not indicated good Javanese culture character in the use of Javanese attitude. One of the good characters in the use of Javanese is good manners [6] when communicate with other. Good manners in Javanese is using Javanese according rule of unggah-ungguh. Speaker must concern whom they speak to, content communication, and where communication take placed [7].

That condition must get solution. Researcher would make solution by developing the content of local Javanese subject curriculum. Developing content standard (CS) is done by revising and innovating the KTSP 2008. Revising of fundamental competence (FC) component would be done by adding and adapting four competence domains; religious attitude domain, social domain, knowledge, and skill. Innovating would be done by formucursiveg of FC focused on 
literacy. Core competence (CC) component adapts to curriculum $2013 \mathrm{CC}$ which is decided by government [8].

Literacy focus is choosen because the nature of literacy is to mêlèk or to be literate in Javanese culture. Mêlèk of Javanese culture is not only about comprehension, but also about how to behave and understand the customs, which reflect in Javanese use. Students will have the feeling of belonging, involving, and conserving (handarbeni, angrungkepi, dan ngleluri) if they are literal in Javanese culture. Mêlèk of culture has the same meaning with literacy culture [9].

The formucursiveg of FC includes purpose, material/content, method, and evaluation [10]. General purpose of learning FC would be adjusted with position and function Javanese as local territory language and medium of communication. Special purposes of FC are changing language attitude and behavior. Material/content includes the four communicative competences [11] on all literacy levels [12] agree with cognitive development, interest, and students need [13]. The method includes approach, strategic, and media/learning resource.

Learning literacy approach has eight basic principles. Literacy prominent activity are reading/listening (critical thinking/reflecting by oral/written) and writing (product/written/publication). This activity could be introduced as learning strategies [15]. Media and learning resource [8] were provided in order to get interactions with texts continually [16]. Text option would be stressed on the text which has rich good manner value in Java culture. The interaction between students and text was done by using all literacy components [17]. All of those have purpose to give students get language experience freely. Evaluation includes understanding grammatical rule, function, and meaning; implementation of language rule, literature [18], and Java culture in order to achieve text as result of literacy activity based on students' interest and capability.

\section{METHOD}

This research employed qualitative approach [19]. Research method used development education research mode which was developed by Brog and Gall. This mode was modificated by Puslitbang Depdiknas. Originally, Brog and Gall mode consist of 1) researching and data collecting, 2) planning, 3) developing early form product, 4) early experiment field, revising prominent product, 5) prominent experiment field, 7) operational experiment field, 8) revising end product, 9) socialization, and 10) implementation [20]. Puslitbang Depdiknas [21] modified Brog and Gall's mode into five steps: analyzing product which will been developed, developing early product, validating and revising with experts' help, little scale experimenting and revising product, and breading level experiment and end product [12]. Researcher adapted Brog and Gall mode on five stages restriction: introduction study stage, developing product, validation, field experiment, and socialization.

Research data was obtained on research process. Those are process information of product development, test quality of product document, and test quality of usage product. Test quality was done by using validation techniques [22]. Validation was applied on all aspect and result of development product. Data analysis technique about information of quality product was done by using Likert's scale. Likert's scale as the quantification was used to count the number of responses in each aspect of development product components. Likert's scale starts from very positive value until very negative value. Qualitative descriptive analyze was done to consider of product condition. The product needed perfection by revision. And manual interval value scale was used in drawing conclusion criteria from data.

The research was done on education year 2014/2015 2015/2016. Subject research for little field experiment, limited field experiment, broad field experiment were students the $7^{\text {th }}$ grade of three junior high school at Lamongan region.

\section{RESULTS AND DISCUSSION}

\section{A. Results}

The results of this study shows that mode document of SMP Javanese local content curriculum- literacy focus (JLCCLF) for 7 th class. Literacy is a focus of developing curriculum components. They are aim, content, method, and assessment. The mode document was followed by learning set of equipment. The improvement of Javanese in school was resulted of experiment JLCC-LF stage.

SMP JLCC-LF document mode for 7th class is a complete document with curriculum 2013 (K13) format, consists of chapter I: Introduction, chapter II: Content Standard, and chapter III: Learning Set of Equipment. From the results of this research, researcher formulated fundamental competence (FC) as follows:

1) FC 1.1 Appreciate and grateful to God that Javanese can be an indication of Java ethnic in good manner Javanese usage; 1.2 Appreciate and grateful to God that Javanese can be a medium of communication, oral and written.

2) FC 2.1 Behave hones, discipline, responsible, care, and good manner in oral and written communication; 2.2 Behave hones, discipline, responsible, care, and good manner in give response of literature, art work, cultural work, and science which was wrote in Javanese.

3) FC 3.1 Understand text content, 3.2 identifies text structure and language element of text, 3.3 determine elements of establishing text, 3.4 draw conclusion of narration text, descriptive text, poetry, expository text according to role, function, and meaning text use cursive letter and Java letter in oral and written form.

4) FC 4.1 Response text, 4.2 classify text genre, 4.3 reflect text, 4.4 write narrative text, descriptive, poetry, expository according rule, function, and meaning of the cursive letter and Java letter text in oral and written.

Learning of equipment mode consists of syllabus, lesson plan activity, and material sheet with work sheet and assessment sheet in it. Material sheet is a text written by teacher or text modification which was adjusted with learning 
purpose. The text contained good manner value in Java culture. Subject matter was managed based on competence communicative components: 1) text as prominent medium, 2) language knowledge (rule word cursive/Javanese, rule speech cursive/Javanese, and good manner available in small dictionary), and 3) literature knowledge (text, good speech). There are two students' work sheet group work sheet and independence work sheet. The results of group worksheets were presented. The result of independence work sheet acted as personal portfolio and at the end of students' task, they needed to publish their writing in an anthology together with teacher [23]. Students learning series were text building of the field, modeling of text, joint construction of text, and independent construction of the text.

Based on validation results, validator team asserted that SMP JLCC-LF document mode for $7^{\text {th }}$ class is suitable as an object study for local content curriculum mode. Generally, SMP JLCC-LF document mode for $7^{\text {th }}$ class had met a demand fundamental and principal development of local content curriculum. Formucursiveg FC in the content standard had reflected literacy focus on every component. Composing learning of equipment referred to literacy learning based text. Developing SMP JLCC-LF for $7^{\text {th }}$ class had met a demand school needed, especially local content Javanese curriculum because it meet with K13 from Education and Cultural ministry.

Based on collaborator observation, teacher response, students response, researcher drew conclusion that

1) SMP JLCC-LF for $7^{\text {th }}$ class very flexible and relevant to be elaborated in the learning plan and implementation activity. Learning activity would be effective, efficient, and practice. Students achieved learning purpose. Teacher can arranged learning situation to give students adequate language experience.

2) SMP JLCC-LF for $7^{\text {th }}$ class very flexible and relevant to be adjusted with school infrastructure, school situation, need and teacher ability in the teaching today and tomorrow.

3) SMP JLCC-LF for $7^{\text {th }}$ class gives broad opportunity for Javanese teachers to make creation and innovation when they plan and do their job.

4) Continuing interaction with text gave students freedom to do in language activity. Students have bravery and confident to use Javanese in class or out class.

5) Language experience and understanding of good manner value Java culture can be a student substance to master of discourse. Students can improve their language usage based on rule, function, and meaning. Students of SMP Negeri 2 Sugio can wrote poetry and narrative text. The writing were made in anthology "Kembang Mayang" for narrative text and "Sekar Rinonce" for poetry.

\section{B. Dicussion}

\section{a. Local Curriculum Mode of SMP JLCC-LF for $7^{\text {th }}$ Class}

Mode of local curriculum development for K13 was adjusted with manual composing of local content curriculum. Developing would consider prime purpose learning of local content in school. It was used to form students' understanding about local special quality and wisdom at their territory. General purpose of local content learning is to give attitude, knowledge, and skill students who needed for identify and love their nature, social, culture territory; conserve, develop specify quality, and wisdom at their territory which give benefit for their selves and their improvement to support national building.

Polite behaviors were not restricted on users' language knowledge, but also include honesty, toleration, discipline, responsibility, care, and confidence. Good manner value have relevance with life in multinational interrelation [24]. Good manner can be a filter to foreign cultures which come to Indonesia freely, keep national interest, and keep global challenge. Therefore, Javanese and Java literature must be taught, conserved, and developed by Javanese owners. One of the ways to realize that is the teaching Javanese for Javanese user.

The learning mode used was SMP JLCC-LF for $7^{\text {th }}$ Class is learning mode literacy focused as manual in every the learning plan activity [23]. They are

1) Management subject matter is directed to communicative competence with based text in it. The learning components consist of 1) text as prime medium, 2) language knowledge, and knowledge of literature (wisdom speech text). Subject matter management of components is direct related to culture elements as a background Javanese user which good behaviour in it.

2) Class management was designed by classical learning in elaborate perception (building text), building context, building text together, and independent building text to measure learning achieve individually [8]. The purpose of the class management is to form language activity more interactive and language ability more trained in receptive and productive. Implementation of learning activity to be opened for teacher and learner. Teacher can be a facilitator and motivator maximally [8].

3) Management of assessment, group task, individual task, and home work can be finished easily. Teacher gives students the way how to do with students' task individually, haw to do the test, and how to finish product independently. Assessment aspect in process and result learning has been completed with assessment equipment which consists of indicators, assessment instrument, and assessment manual. Result learning assessment sheet have been completed to give teacher ease when teacher asses students result learning more realistic, measurable, and valid. Indicator of effectiveness of assessment equip instrument appeared from analyze students achieve. Those have distinguishing and difficulties levels significantly. 
Based on above explanation, development of SMP JLCCLF for $7^{\text {th }}$ Class can be a study or previous step to develop Javanese local curriculum in accordance with K13. SMP JLCC-LF for $7^{\text {th }}$ Class can makes teacher to improve their learning plan, process, and assessment in Javanese learning activity at school.

\section{b. $\quad$ Student Culture Literacy}

Literacy is a part of culture for Javanese people. That culture literacy evidence are the old treasure Java literature and non-literature texts which have been avowed the world literature treasure. Along with development era and progress of era, however, read and write as Java people literacy culture unappeared. Generally, student of SMP almost forget reading and writing activity because replaced by audio visual culture. Modern technology replace culture literacy. Students tended to passionate with their own world. Students were less able to communicate and socialize with other.

Today phenomena is $7^{\text {th }}$ class students of SMP Negeri 2 Sugio -as Javanese user- begin to leave their language. Students fear of one to use Javanese because they less understand Javanese role of undha usuk as an identity of Javanese when speaker is talking [7]. Students have not can classified who they speak with. For example, when they are speaking with their teacher, respecting their teacher must be identified by choosing right words such as panjenengan, diutus, dikersaken, dhahar.

The conditions have shown that students' literacy ability just until performativity level, it is unappropriated yet. Students of SMP should be epistemic literacy level [12]. So, students should have culture literacy. Students should have custom culture literacy in order to understand how to use Javanese receptively, reflectively, and productively [15].

Improving students' literacy ability should be done by giving students flexibility and facilitation to get language experience broadly. Students flexibility in Javanese usage should be gave by teacher to communicate according students' ability freely. For example, when students communicate with other, teacher tolerate with students mistake. Furthermore, teacher improve student mistake at the end lesson. Facilitation for student is available various text as learning medium [15].

Teacher should consider student language ability, cognitive ability, psychology, and closeness text with student life in choosing text [13]. The chosen text should load many good manner values in Java culture, as in "Srikandi Senopati Pandhawa". This text is about a woman bravery as a leader of army. This text can be used to dig responsible value, discipline, confident, and care is like the main character. Poetry of Dhandanggula wrote by Mangkunegaran IV [25] contains value, care, responsibility, good manner, etc.

Continuing student interaction with text would result appropriate language experience. Student should be gave various text genre to be read, identified, classified of the kind of text, drew conclusion, and made new wrote from the text [14]. Language experience and culture literacy can pull student to realize product language activity oral and written critically [26].
Student product of SMP Negeri 2 Sugio-Kembang Mayang and Sekar Rinonce- are the evidence of learning using SMP JLCC-LF for $7^{\text {th }}$ Class. Therefore, learning using SMP JLCC-LF for $7^{\text {th }}$ Class can grow culture literacy.

\section{CONCLUSON}

JLCC-LF is needed in Javanese lesson. JLCC-LF is a bridge for Javanese learner to love their language. Student who less care their mother tongue will be challenged to dig their language potential orally, written, and creative. Student who unwilling use their language to communicate will have self-confident to use their language. Growing the culture literacy should be pulled and supported by JLCC-LF. Text which used as student learns media can give student inspiration to seek other text in order to rich language and literature experience. Additional, student would be motivated to product various text as follow-up of learning activity in their class. Student written are one of evidence that student culture literacy through JLCC-LF have grown. We hope that all this result research can act as the initial step of research about Java language and literature in the future. Thus, learning Javanese can be a power to return culture literacy which had been developed in Java society.

\section{REFERENCES}

[1] Peraturan Menteri Pendidikan dan Kebudayaan No 79 tentang muatan lokal kurikulum 2013. Jakarta: Depdikbud, 2014.

[2] Peraturan pemerintah no 32 tentang standar nasional Pendidikan Jakarta: Depdiknas, 2013.

[3] Peraturan Menteri Pendidikan dan Kebudayaan no 81a tentang Implemntasi kurikulum 2013. Jakarta: Depdikbud, 2013.

[4] Surat Edaran Dinas Pendidikan Propinsi Jawa Timur No. 045.2/4340/I.03.07/2013 tentang Pembelajaran Bahasa Daerah, 2013.

[5] Kurikulum Tingkat Satuan Pendidikan (KTSP) 2006 Revisi 2008 Mata Pelajaran Bahasa Daerah, Dinas Pendidikan Provinsi Jawa Timur, 2008.

[6] S. Y. Sudikan, and B. Nuryanta, Pengembangan Pembeljaran Unggah-Ungguh Bahasa Jawa yang berorientasi Pembentukan Budi Pekerti Luhur Anak di SMP Provinsi Jawa Timur. Surabaya: UNESA University Press, 2013.

[7] S. Padmosoekotjo, Gegaran Sinau Basa Jawa: Memetri Basa Jawa, Surabaya: PT Citra Jaya Murti, 1995.

[8] Depdikbud. Kurikulum Nasional 2013, Jakarta, 2013.

[9] UNESCO, Education for All, Literacy for live, EFA Global Monitoring Report Education for All, The United Nations Educational, Scientific and Cultural Organization: 7, Place de Fontenoy, 75352 Paris 07 SP, France, 2006.

[10] T. Ruhimat, et al. Kurikulum \& Pembelajaran. Tim Pengembang MKDP Kurikulum dan Pembelajaran, UPI Bandung, Jakarta: Rajawali Press, 2011.

[11] S. J. Savignon, Communicative Competence: Theory and Slassroom Practice: Massachusetts: Addison-Wesley Publishing Company, 1983.

[12] B. Wells, Apprenticeship in Literacy. In Interchange 18,1/2:109-123, 1987.

[13] E.V. Clark, and H. Clark, Psyochology and Language: An Introduction to Psychololinguistics. New York: Harcourt Brace Jovanovich, Publishers, 1977.

[14] R Kern, Literacy and Language Teaching. Oxford: Oxford University Press, 2000.

[15] R. Eanes, Conten Area Literacy, Teaching for Today and Tomorrow. New York: Delmar, 1997. 
[16] Mahsun, "Pembelajaran Bahasa Indonesia menggunakan Pendekatan Teks”. Kompas Edu.27 Februari 2013. Accessible on 8 April 2013.

[17] Krisnan, Literasi: Mengenal Konsep Dasar dan 6 Komponennya https://meenta.net/konsep-dan-komponen-literasi/baca/1/13/2018, 2017.

[18] Y. Bambang, Pengantar Teori Belajar Bahasa. Surabaya: UNESA University Press, 2013

[19] Sugiyono, Metode Penelitian: Pendidikan Kuantitatif Kualitatif dan R \& D. Bandung: Alfabeta, 2010

[20] Borg \& Gall, and M.D. Gall, Educational Research: An Introduction, Fifth Edition. New York: Longman, 1989.

[21] Depdiknas, Metode Penelitian Pengembangan. Jakarta: Depdiknas. 2008.

[22] S.N. Syaodih, Metode Penelitian Pendidikan. Bandung: Program Pasca Sarjana Universitas Pendidikan Bandung bekerjasama dengan PT Remaja Rosdakarya, 2010.

[23] Rusijono dan B. Yulianto, Assesmen Pembelajaran. Surabaya: Unesa dan Dinas Pendidikan Kota Surabaya, 2008.
[24] S. Djoko, Menghormati Keragaman, meneguhkan Kejawaan: Politik Bahasa dan Sastra Jawa di tengah Kemajemukan. Makalah Rapat Koordinasi dan sikronisasi Pelestarian Sastra daerah dan bahasa Jawa Menyongsong Kongres Bahasa Jawa ke-5, di Hotel satelit Surabaya, 7-9 Oktober 2009.

[25] KGPAA Mangkunegara. Serat Darmawasita. Bait/Pada Dhandhanggula, 1878

[26] Suyono, Pembelajaran Efektif Dan Produktif Berbasis Literasi: Analisis Konteks, Prinsip, dan Wujud Alternatif Strategi Implementasinya di Sekolah. Bahasa dan Seni, Tahun 37, Nomor 2 , 2009. 